\title{
ИССЛЕДОВАНИЕ ПРОИЗВОДНЫХ ГИДРОКСАМОВЫХ КИСЛОТ В КАЧЕСТВЕ ГИБРИДНЫХ НDАС/VEGFR-2 ИНГИБИТОРОВ
}

\author{
О.В. Тиньков ${ }^{1}$, Г.В. Фомов², Л.Д. Григорьева ${ }^{3}$, Д.С. Хачатрян ${ }^{4}$, \\ А.В. Колотаев ${ }^{4}$, В.Н. Осипов ${ }^{5}$, В.Ю. Григорьев ${ }^{6}$
}

${ }^{1}$ Кафедра фармакологии и фармацевтической химии, Приднестровский Государственный Университет им. Т.Г. Шевченко,

3300, Молдова, Приднестровье, Тирасполь, ул. Мира, 33.

${ }^{2}$ Кафедра хирургии с циклом онкологии, Приднестровский Государственный Университет им. Т.Г. Шевченко, 3300, Молдова, Приднестровье, Тирасполь, ул. Мира, 33.

${ }^{3}$ Факультет фундаментальной физико-химической инженерии, Московский Государственный Университет им. М.В. Ломоносова, 119991, Россия, Москва, Ленинские горы, 1, стр.51.

4Лаборатория природных соединений ККХИ, Национальный исследовательский центр «Курчатовский институт», 123182, Москва, пл. Академика Курчатова, д. 1.

${ }^{5}$ Лаборатория химического синтеза, НМИЦ онкологии имени Н.Н. Блохина Министерства здравоохранения Российской Федерации,

115478, Москва, Каширское шоссе, 24.

${ }^{6}$ Отдел компьютерного молекулярного дизайна,

Институт физиологически активных веществ Российской академии наук, 142432, Московская область, Черноголовка, Северный пр. 1.

DOI: 10.19163/MedChemRussia2021-2021-525

E-mail: oleg.tinkov.chem@mail.ru

Гистондеацетилазы (HDAC) и рецептор фактора роста сосудистого эндотелия, тип 2 (VEGFR-2) являются многообещающими мишенями для создания противоопухолевых препаратов. В настоящее время наиболее перспективной стратегией в борьбе с онкологическими заболеваниями является создание гибридных лекарств, одновременно действующих на несколько физиологических мишеней. Значительный интерес с точки зрения создания гибридных противоопухолевых средств представляют соединения, содержащие одновременно хиназолин и гидроксамовую кислоту, так как данные фрагменты по отдельности присутствуют в уже успешно применяемых противоопухолевых лекарственных средствах. В настоящем исследовании построены адекватные QSAR модели, используя которые, мы провели виртуальный скрининг с целью отбора из проприетарной базы данных, представленной 394 веществами, наиболее перспективных соединений - бифункциональных HDAC/NEGFR-2 ингибиторов. С целью экспериментальной валидации виртуального скрининга из вышеописанной серии соединений было отобрано 6 синтезированных ранее веществ [1] и оценена in vitro их способность ингибировать HDAC6. Предложенная QSAR модель позволила правильно предсказать класс активности всех протестированных соединений. Одно из предложенных соединений ингибирует HDAC6 $\left(\mathrm{IC}_{50}=0,99\right.$ нМ) почти в 9 раз сильнее, чем известный ингибитор HDAC препарат Вориностат.

\section{Литература}

[1] А.А. Вартанян, Д.А. Хоченков, Ю.А. Хоченкова, Ю.С. Мачкова, Д.С. Хачатрян, А.В. Колотаев, А.Н. Балаев, К.А. Охманович, В.Н. Осипов. Биоорганическая химия, 2020, 46 (2), 207-219. 